\title{
Effects of adjunct testosterone on cardiac morphology and function in advanced cancers: an ancillary analysis of a randomized controlled trial
}

Jessica M. Scott ${ }^{1}$, E. Lichar Dillon², Michael Kinsky³, Albert Chamberlain², Susan McCammon ${ }^{4}$, Daniel Jupiter ${ }^{5}$, Maurice Willis ${ }^{2}$, Sandra Hatch ${ }^{6}$, Gwyn Richardson 7 , Christopher Danesi ${ }^{2}$, Kathleen Randolph ${ }^{2,8}$, William Durham², Traver Wright ${ }^{2,8}$, Randall Urban ${ }^{2}$ and Melinda Sheffield-Moore ${ }^{2,8^{*}}$ (D)

\begin{abstract}
Background: Adjunct testosterone therapy improves lean body mass, quality of life, and physical activity in patients with advanced cancers; however, the effects of testosterone on cardiac morphology and function are unknown. Accordingly, as an ancillary analysis of a randomized, placebo-controlled trial investigating the efficacy of testosterone supplementation on body composition in men and women with advanced cancers, we explored whether testosterone supplementation could prevent or reverse left ventricular (LV) atrophy and dysfunction.

Methods: Men and women recently diagnosed with late stage ( $\geq \mid \mathrm{IB})$ or recurrent head and neck or cervical cancer who were scheduled to receive standard of care chemotherapy or concurrent chemoradiation were administered an adjunct 7 week treatment of weekly intramuscular injections of either $100 \mathrm{mg}$ testosterone $(T, n=1 \mathrm{M} / 5 \mathrm{~F})$ or placebo ( $P, n=6 \mathrm{M} / 4 \mathrm{~F})$ in a double-blinded randomized fashion. LV morphology (wall thickness), systolic function (ejection fraction, EF), diastolic function (E/A; $\left.E^{\prime} / E\right)$, arterial elastance (Ea), end-systolic elastance (Ees), and ventriculararterial coupling (Ea/Ees) were assessed.

Results: No significant differences were observed in LV posterior wall thickness in placebo (pre: $1.10 \pm 0.1 \mathrm{~cm}$; post: $1.16 \pm 0.2 \mathrm{~cm} ; p=0.11$ ) or testosterone groups (pre: $0.99 \pm 0.1 \mathrm{~cm}$; post: $1.14 \pm 0.20 \mathrm{~cm} ; p=0.22$ ). Compared with placebo, testosterone significantly improved LVEF (placebo: $-1.8 \pm 4.3 \%$; testosterone: $+6.2 \pm 4.3 \% ; p<0.05$ ), Ea (placebo: $0.0 \pm 0.2 \mathrm{mmHg} / \mathrm{mL}$; testosterone: $-0.3 \pm 0.2 \mathrm{mmHg} / \mathrm{mL} ; \mathrm{p}<0.05$ ), and Ea/Ees (placebo: $0.0 \pm 0.1$; testosterone: $-0.2 \pm 0.1 ; p<0.05)$.
\end{abstract}

Conclusions: In patients with advanced cancers, testosterone was associated with favorable changes in left ventricular systolic function, arterial elastance, and ventricular-arterial coupling. Given the small sample size, the promising multisystem benefits of testosterone warrants further evaluation in a definitive randomized trial.

Trial registration: This study was prospectively registered on ClinicalTrials.gov (NCT00878995; date of registration: April 9, 2009).

Keywords: Testosterone, Cardiac function, Cachexia

\footnotetext{
* Correspondence: msheffield-moore@tamu.edu

${ }^{2}$ Department of Internal Medicine, The University of Texas Medical Branch,

Galveston, TX, USA

${ }^{8}$ Department of Health and Kinesiology, Texas A\&M University, 155 Ireland

St., College Station, TX TX 77845, USA

Full list of author information is available at the end of the article
}

(c) The Author(s). 2019 Open Access This article is distributed under the terms of the Creative Commons Attribution 4.0 International License (http://creativecommons.org/licenses/by/4.0/), which permits unrestricted use, distribution, and reproduction in any medium, provided you give appropriate credit to the original author(s) and the source, provide a link to the Creative Commons license, and indicate if changes were made. The Creative Commons Public Domain Dedication waiver (http://creativecommons.org/publicdomain/zero/1.0/) applies to the data made available in this article, unless otherwise stated. 


\section{Background}

Cancer cachexia is a complex, multifactorial syndrome characterized by a progressive loss of skeletal muscle mass with or without loss of fat mass that cannot be fully reversed by conventional nutritional support [1]. Cachexia occurs in 50 to $80 \%$ of advanced cancer patients and is associated with decreased mobility [2], reduced response to chemotherapy [3], and is estimated to directly account for more than $20 \%$ of cancer-related deaths [2]. There are no established therapies for cancer cachexia; accordingly, identification and testing of effective interventions are of major clinical importance in this at-risk population.

Cancer cachexia involves not only the loss of skeletal muscle, but also results in pathologic alterations within the heart $[4,5]$. The first report linking tumor burden and cardiac atrophy was first published in 1904 [6], and was extensively outlined using autopsies by Hellerstein and Santlago-Stevenson in 1950 [7]. More recent preclinical findings indicate that cardiac muscle loss occurs to a similar degree as in skeletal muscles, with concomitant impairment in systolic and diastolic function $[8,9]$. Collectively, the global nature of cachexia portends the requirement for multifactorial treatment strategies with the capacity to augment or reverse whole-organism atrophy.

Testosterone therapy has been used in patients exposed to atrophic stimuli [10] to increase muscle strength and bone mineral density $[11,12]$. The heart is also a target organ for steroids; there are receptors with a high affinity for testosterone in cardiomyocytes [13], suggesting that testosterone supplementation may also improve cardiac morphology and function. In support, a meta-analysis of randomized placebo-controlled studies found that testosterone administered to patients with chronic heart failure reduced systemic vascular resistance and increased both cardiac output and overall exercise capacity [14]. However, whether there are similar salutary cardiovascular effects of testosterone in patients with advanced cancers is not known. Accordingly, as an ancillary analysis of a randomized, placebo controlled trial investigating the efficacy of testosterone supplementation on body composition in men and women with advanced cancers [15], we explored whether testosterone supplementation could prevent or reverse left ventricular (LV) atrophy and dysfunction.

\section{Methods}

\section{Patients and study design}

Details of the design, rationale, and primary results of study have been published elsewhere [15]. This is an ancillary analysis of a RCT (NCT00878995) among men and women with histologically-confirmed advanced or recurrent squamous cell carcinoma of the cervix (stages IIB, IIIA, and IIIB) or head and neck squamous cell carcinoma (stage III or IV) conducted at the University of Texas Medical Branch at Galveston, TX. Major eligibility criteria were: [1] loss of at least $5 \%$ of body mass over the past 12 months, [2] Eastern Cooperative Oncology Group score of 0 or 1, [3] score of $>23$ points on the 30 point Mini Mental State Examination. All study procedures were reviewed and approved by the institutional review board. Participation in both intervention groups continued for a maximum of 7 weeks or until unacceptable toxicity or withdrawal of consent, whichever came first. Patients were randomly allocated in blocks of three to receive weekly injections of either $100 \mathrm{mg}$ of testosterone enanthate $(n=10)$ or placebo $(n=14)$. Interventions were matched in terms of setting (clinicbased), and length (7 weeks). All outcomes were evaluated at pre-randomization (study treatments were initiated $\leq 14$ days) and were repeated within $\leq 7$ days of the final treatment session at postintervention (month 3 ).

\section{Intervention}

A testosterone replacement paradigm commonly used to treat hypogonadal men was chosen to include weekly intramuscular injections of either $100 \mathrm{mg}$ testosterone enanthate or placebo (sterile saline) over a period of 7 weeks. Testosterone and placebo injections were given by a nurse using an opaque syringe to obscure visual differences between testosterone and placebo.

\section{Cardiac structure and function}

Patients underwent two-dimensional transthoracic and pulsed Doppler imaging by use of a commercial ultrasound system (iE33, Phillips Healthcare). Images were obtained by one experienced sonographer in the long axis, short axis, and apical 4 chamber views according to the American Society of Echocardiography guidelines [16] to determine LV wall thickness, end-diastolic volume (EDV), end-systolic volume (ESV), and LVEF. LV volumes were calculated using the biplane Simpson method. Pulsed Doppler recordings were employed to assess diastolic filling; in particular, early (E) and atrial (A) peak mitral inflow velocities were measured and the ratio of early to late diastolic filling velocity (E:A) was calculated. Tissue Doppler data were used to assess mitral annular velocity (E'). The ratio of $E / E^{\prime}$ was also used to assess diastolic function. Images were analyzed off-line by experienced technicians blinded to group allocation. A minimum of three consecutive cardiac cycles were measured and averaged.

End-systolic pressure (ESP) was calculated as $0.9 \times$ brachial systolic blood pressure, a noninvasive estimate that accurately predicts LV pressure-volume loop measurements of ESP [17]. End-systolic elastance (Ees) was calculated as Ees $=\mathrm{ESP} / \mathrm{ESV}$, effective arterial elastance (Ea) was calculated as $\mathrm{Ea}=\mathrm{ESP} / \mathrm{SV}$, and ventricular- 
vascular coupling was determined as Ea/Ees [18]. Systemic vascular resistance (SVR) was calculated as mean arterial pressure/CI $\times 80$.

\section{Statistical analysis}

Repeated-measures ANOVA was initially used to compare means between groups. Because of the small sample size and large amount of variability in the data, nonparametric tests were carried out at each level of intensity and at each time of measurement. Comparisons among groups were performed using the Kruskal-Wallis test. When differences were determined to be significant, pairwise comparisons were made using the MannWhitney method. The association between baseline cardiac morphology and function and change with testosterone was explored with Pearson correlation coefficient. Values are means $\pm \mathrm{SD}$; significance level was set at 0.05 .

\section{Results}

\section{Patient characteristics}

Men and women recently diagnosed with late stage (IIB or higher) or recurrent head and neck or cervical cancer who were scheduled to receive standard of care chemotherapy or chemoradiotherapy were recruited to participate. A total of 28 potentially eligible patients were contacted for the study, and 24 (86\%) were randomly grouped and administered an adjunct 7 weeks regimen of weekly intramuscular injections of either $100 \mathrm{mg}$ testosterone or placebo. Of these, 16 (67\%) completed cardiac assessments (testosterone, $n=1 \mathrm{M} / 5 \mathrm{~F}$; placebo, $n=6 \mathrm{M} / 4 \mathrm{~F})$. No significant differences were found in the baseline characteristics between placebo and testosterone groups (Table 1).

\section{Testosterone supplementation}

Pre-study average total serum testosterone levels were significantly different between males and females (328 \pm $420 \mathrm{ng} / \mathrm{dL}$ and $17 \pm 14 \mathrm{ng} / \mathrm{dL}$ respectively, $p<0.001$ ). Testosterone levels in females in the placebo group were unchanged from pre- $(16 \pm 9 \mathrm{ng} / \mathrm{dL})$ to post-intervention $(23 \pm 24 \mathrm{ng} / \mathrm{dL} ; p=0.40)$ whereas testosterone levels were increased in the testosterone group (pre: $19 \pm 17$ ng/dL; post: $644 \pm 327 \mathrm{ng} / \mathrm{dL} ; p=0.01)$. Testosterone levels in males in the placebo group decreased from $354 \pm 193 \mathrm{ng} / \mathrm{dL}$ to $342 \pm 174 \mathrm{ng} / \mathrm{dL}(p=0.80)$. Only one male was randomized into the testosterone group; serum testosterone level increased from 177 to $885 \mathrm{ng} / \mathrm{dL}$. Estrogen values remained below $62 \mathrm{pg} / \mathrm{mL}$ for all subjects and there were no changes in response to testosterone treatment.
LV morphology, resting heart rate, and blood pressure No significant differences were observed in LV posterior wall thickness in placebo (pre: $1.10 \pm 0.1 \mathrm{~cm}$; post: $1.16 \pm$ $0.2 \mathrm{~cm} ; p=0.11$ ) or testosterone group (pre: $0.99 \pm 0.1$ $\mathrm{cm}$; post: $1.14 \pm 0.20 \mathrm{~cm} ; p=0.22$ ); Fig. 1 . No differences between groups in change in resting heart rate (placebo: $+3 \pm 11 \mathrm{bpm}$; testosterone: $+6 \pm 11 \mathrm{bpm} ; p=0.39)$ or mean arterial pressure (placebo: $+3 \pm 12.1 \mathrm{mmHg}$; testosterone: $-5 \pm 12.1 \mathrm{mmHg} ; p=0.28$ ) were observed. There was no significant correlation between baseline values and change in LV morphology $(r=0.48)$.

\section{LV volumes, systolic, and diastolic function}

No differences in end diastolic volume (EDV) or end systolic volume (ESV) were observed in the placebo (EDV, pre: $118.9 \pm 16.3 \mathrm{~mL}$, post: $119.3 \pm 16.5 \mathrm{~mL} ; p=0.95$; ESV, pre: $46.9 \pm 13.3 \mathrm{~mL}$, post: $49.2 \pm 8.2 \mathrm{~mL} ; p=0.62)$ or testosterone group, (EDV, pre: $109.5 \pm 16.3 \mathrm{~mL}$, post: $116.0 \pm$ $16.5 \mathrm{~mL} ; p=0.16$; ESV, pre: $46.2 \pm 13.3 \mathrm{~mL}$, post: $41.2 \pm 8.2$ $\mathrm{mL} ; p=0.18)$. There was a significant difference in change in stroke volume between the placebo $(-1.9 \pm 5.3 \mathrm{~mL})$ and testosterone $(+11.5 \pm 5.3 \mathrm{~mL})$ groups (Fig. 2a). There was a significant difference in change in LV ejection fraction (LVEF) between the placebo $(-1.8 \pm 4.3 \%)$ and testosterone $(6.2 \pm 4.3 \%)$ groups $(p=0.02)$ (Fig. 2b). There was a significant negative association between baseline and change in LV ejection fraction in the testosterone group $(\mathrm{r}=0.95 ; p<0.05)$. Diastolic function assessed by E/A (placebo pre: $1.1 \pm 0.3 \mathrm{~cm} / \mathrm{s}$; post: $1.3 \pm 0.4 \mathrm{~cm} / \mathrm{s} ; p=0.35$; testosterone pre: $1.1 \pm 0.3 \mathrm{~cm} / \mathrm{s}$; post: $1.0 \pm 0.4 \mathrm{~cm} / \mathrm{s} ; p=0.63$ ) and E/E' (placebo pre: $6.0 \pm 2.0$; post: $5.7 \pm 1.6$; $p=0.75$; testosterone pre: $7.7 \pm 2.0$; post: $5.7 \pm 1.6 ; \mathrm{p}=0.63$ ) (Fig. $2 \mathrm{c}$ ) was preserved in both groups. Absolute changes in volumes, systolic, and diastolic function are presented in Additional file 1.

\section{Ventricular-vascular coupling}

End-systolic elastance (Ees) was unchanged in both groups (placebo pre: $2.4 \pm 0.7 \mathrm{mmHg} / \mathrm{mL}$; post: $2.4 \pm$ $0.5 \mathrm{mmHg} / \mathrm{mL} ; p=0.79$; testosterone pre: $2.4 \pm 0.7$; post: $2.4 \pm 0.5 ; p=0.85)$. There was a significant difference between groups in change in systemic vascular resistance (SVR, placebo: $45.7 \pm 166.9$ dynes $/ \mathrm{sec} / \mathrm{cm}^{5}$; testosterone: $-359.3 \pm 166.9$ dynes $/ \mathrm{sec} / \mathrm{cm}^{5}$; Fig. 3a), effective arterial elastance (Ea, placebo: $0.0 \pm 0.2$ $\mathrm{mmHg} / \mathrm{mL}$; testosterone: $-0.3 \pm 0.2 \mathrm{mmHg} / \mathrm{mL}$; Fig. $3 \mathrm{~b}$ ), and ventricular-vascular coupling (Ea/Ees, placebo: $0.0 \pm 0.1$; testosterone: $-0.2 \pm 0.1$; Fig. $3 \mathrm{c}$ ). No significant associations were observed between baseline and change in ventricular-vascular coupling. Absolute changes in ventricular-vascular coupling are presented in Additional file 1. 
Table 1 Demographic and Treatment Characteristics of the Participants

\begin{tabular}{|c|c|c|c|c|}
\hline Characteristic & $\begin{array}{l}\text { All Patients } \\
(n=16)\end{array}$ & $\begin{array}{l}\text { Placebo } \\
(n=10) \\
\end{array}$ & $\begin{array}{l}\text { Testosterone } \\
(n=6)\end{array}$ & $P=$ value \\
\hline Time (mos) from diagnosis to enrollment - mean (SD) & $3.1(3.2)$ & $2.9(3.4)$ & $3.6(3.1)$ & 0.684 \\
\hline Age (yrs) - mean (SD) & $50.9(9.5)$ & $48.4(10.9)$ & $55.0(5.1)$ & 0.189 \\
\hline $\mathrm{BMI}\left(\mathrm{kg} / \mathrm{m}^{2}\right)-$ mean $(\mathrm{SD})$ & $22.1(6.8)$ & $23.9(7.3)$ & $19.3(5.2)$ & 0.200 \\
\hline aExercise behavior (activity score) - mean (SD) & $9.0(8.0)$ & $9.9(9.6)$ & $7.1(3.6)$ & 0.588 \\
\hline Race - no. (\%) & & & & 0.330 \\
\hline Non-Hispanic white & $11(69)$ & $6(60)$ & $5(83)$ & \\
\hline Other group & $5(31)$ & $4(40)$ & $1(20)$ & \\
\hline Sex - no. (\%) & & & & 0.091 \\
\hline Male & $7(44)$ & $6(60)$ & $1(17)$ & \\
\hline Female & $9(56)$ & $4(40)$ & $5(83)$ & \\
\hline Smoking - no. (\%) & $n=16$ & $n=10$ & $n=6$ & 0.355 \\
\hline Never & $4(25)$ & $3(30)$ & $1(17)$ & \\
\hline Former & $7(44)$ & $3(330)$ & $4(67)$ & \\
\hline Current & $5(31)$ & $4(40)$ & $1(17)$ & \\
\hline Disease stage - no. (\%) & $n=15$ & $n=9$ & $n=6$ & 0.852 \\
\hline$\| \mathrm{B}$ & $1(7)$ & $0(0)$ & $1(17)$ & \\
\hline III & $0(0)$ & $0(0)$ & $0(0)$ & \\
\hline$\| \mathrm{II}$ & $4(27)$ & $3(33)$ & $1(17)$ & \\
\hline IV & $0(0)$ & $0(0)$ & $0(0)$ & \\
\hline IVA & $8(53)$ & $5(56)$ & $3(50)$ & \\
\hline IVB & $2(13)$ & $1(11)$ & $1(17)$ & \\
\hline Cancer Type - no. (\%) & & & & 1.000 \\
\hline Cervical & $6(38)$ & $4(40)$ & $2(33)$ & \\
\hline Head/neck & $10(62)$ & $6(60)$ & $4(37)$ & \\
\hline PEG feeding tube - no. (\%) & $6(38)$ & $3(30)$ & $3(50)$ & 0.986 \\
\hline \multicolumn{5}{|l|}{ Current Therapy - no. (\%) } \\
\hline Chemotherapy & $11(69)$ & $6(60)$ & $5(83)$ & 0.985 \\
\hline Radiotherapy & $13(81)$ & $9(90)$ & $4(67)$ & \\
\hline Other Therapy & $0(0)$ & $0(0)$ & $0(0)$ & \\
\hline Prior therapy - no. (\%) & $n=16$ & $n=10$ & $n=6$ & 0.927 \\
\hline Surgery & $2(13)$ & $2(20)$ & $0(0)$ & \\
\hline Chemotherapy & $0(0)$ & $0(0)$ & $0(0)$ & \\
\hline Radiotherapy & $0(0)$ & $0(0)$ & $0(0)$ & \\
\hline Other Therapy & $0(0)$ & $0(0)$ & $0(0)$ & \\
\hline Current Medications - no. (\%) & $n=16$ & $n=10$ & $n=6$ & 0.728 \\
\hline Beta-blocker & $0(0)$ & $0(0)$ & $0(0)$ & \\
\hline ACE inhibitor & $1(6)$ & $1(10)$ & $0(0)$ & \\
\hline ARB & $1(6)$ & $1(10)$ & $0(0)$ & \\
\hline Diuretic & $1(6)$ & $1(10)$ & $0(0)$ & \\
\hline Calcium channel blocker & $1(6)$ & $1(10)$ & $0(0)$ & \\
\hline Aspirin & $3(19)$ & $2(20)$ & $1(17)$ & \\
\hline Statin & $2(13)$ & $2(20)$ & $0(0)$ & \\
\hline Pre-existing conditions - no. (\%) & $n=16$ & $n=10$ & $n=6$ & 0.586 \\
\hline
\end{tabular}


Table 1 Demographic and Treatment Characteristics of the Participants (Continued)

\begin{tabular}{llll}
\hline Characteristic & $\begin{array}{l}\text { All Patients } \\
(n=16)\end{array}$ & $\begin{array}{l}\text { Placebo } \\
(n=10)\end{array}$ & $\begin{array}{l}\text { Testosterone } \\
(n=6)\end{array}$ \\
\hline Peripheral vascular disease & $2(13)$ & $1(10)$ & $1(17)$ \\
Coronary artery disease & $1(6)$ & $1(10)$ & $0(0)$ \\
Osteoporosis & $1(6)$ & $0(0)$ & $0(17)$ \\
Arrhythmia & $0(0)$ & $0(0)$ & $0(0)$ \\
Arthritis & $0(0)$ & $0(0)$ & $0(0)$ \\
Type II diabetes & $2(13)$ & $2(20)$ & $0(0)$ \\
Hyperlipidemia & $2(13)$ & $2(20)$ & $0(0)$
\end{tabular}

Abbreviations: SD standard deviation, $B M I$ body mass index, $A C E$ angiotensin converting enzyme, $A R B$ angiotensin II receptor blockers. ${ }^{a}$ Exercise behavior sum of mild, moderate, and strenuous exercise obtained from ActiGraph 3 axis accelerometry monitors available in a subset of patients $(n=8$ placebo; $n=4$ testosterone). No significant differences between the groups. $P$-values provided are from t-tests when group means were compared or chi-square tests when comparing frequency of cases between the groups

\section{Discussion}

This is the first randomized trial to explore the potential efficacy of testosterone to augment / reverse cardiac morphology and function in patients with advanced cancers. The major new findings of this study were that compared with placebo, testosterone improved LV systolic function, as well as ventricular-vascular coupling. This may have important health implications for patients with cachexia given that this entity has no established evidence-based interventions that improve outcomes.

Changes in cardiac morphology and function may stem from the cancer itself and/or the cardiotoxic effects of cancer therapies [19]. For instance, Springer et al. [8] reported extensive loss of cardiomyocyte volume and replacement with fibrotic tissue among patients who died of pancreatic, lung, and colorectal cancer; however, a subset of patients with significant cancer-related weight loss and cachexia had reduced LV wall thickness and mass compared with cancer patients without cachexia. A reduction in LV mass following anthracycline-based chemotherapy

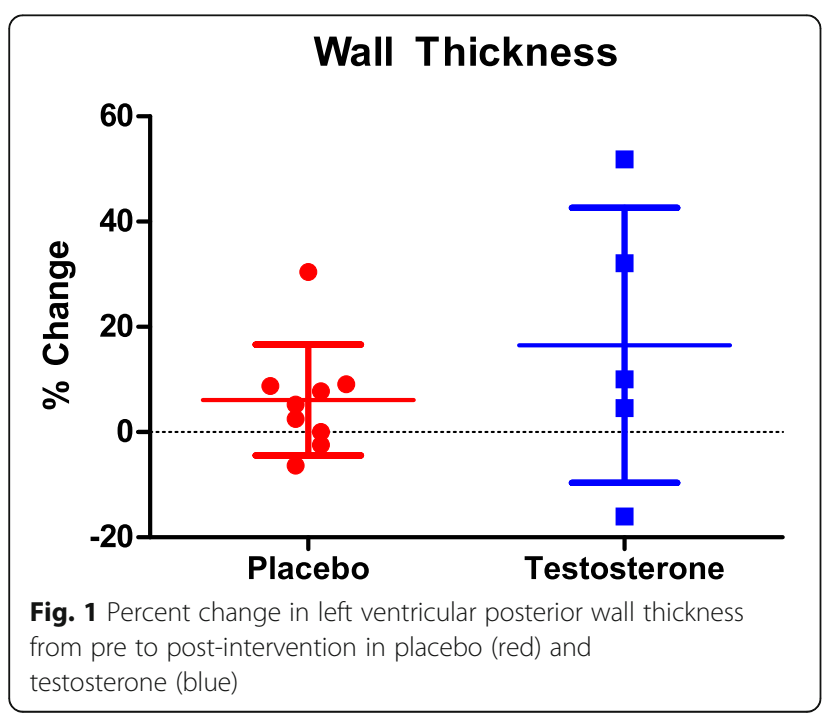

has also consistently been reported $[20,21]$ and is associated with major adverse cardiac events (cardiovascular death, appropriate implantable cardioverter-defibrillator therapy, or admission for decompensated HF) [21]. Of note, average BMI of included patients was $\sim 27 \mathrm{~kg} / \mathrm{m}^{2}$, and whether patients with cachexia were included was not reported [20,21]. The present study confirms and extends previous reports by including patients with advanced cancers, none of whom had been previously treated with cytotoxic therapy or radiotherapy. Collectively, these findings indicate that cardiac alterations in patients with advanced cancers is part of a complex, systemic issue that results in widespread muscle wasting. Accordingly, intervention strategies with multifactorial effects will be required to reverse whole-organism atrophy.

At least 19 studies have assessed the efficacy of pharmacological agents in clinical trials to manage cancer cachexia [22]; however, few have explored the potential salutary effects on cardiac morphology and function. Testosterone therapy has been used in patients exposed to atrophic stimuli [10] to increase muscle strength and bone mineral density [11], and we previously reported that in patients with advanced cancer adjunct testosterone improved lean body mass and was associated with increased quality of life, and physical activity compared with placebo [15]. Previous findings from non-oncology settings indicate that exogenous testosterone may also directly induce physiological cardiac myocyte hypertrophy [23]. For instance, among men with type 1 diabetes, higher total testosterone was associated with higher LV mass and volume [24], and Subramanya and colleagues [25] recently reported that after a median of 9.1 years, higher free testosterone levels were independently associated with an increase in LV mass in women and men in the Multiethnic Study of Atherosclerosis. In RCTs, testosterone treatment improved cardiac biomarkers in patients with type II diabetes [26], and reduced systemic vascular resistance and increased both 


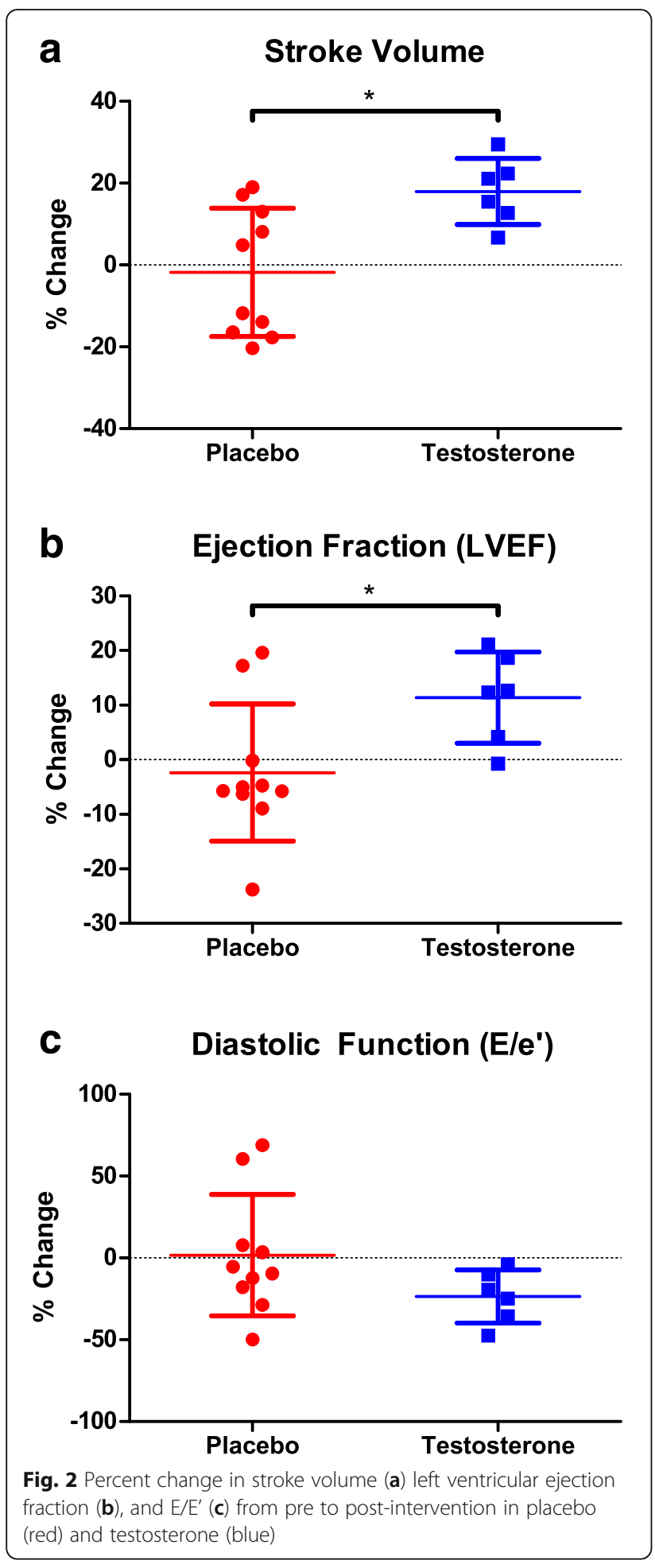

cardiac output and overall exercise capacity in heart failure patients [14]. Similar findings were observed here in patients with advanced cancers; compared with placebo, testosterone improved indices of LV function. In addition, patients with the lowest LV ejection fraction at baseline experienced the greatest improvement with

\section{a Systemic Vascular Resistance (SVR)}

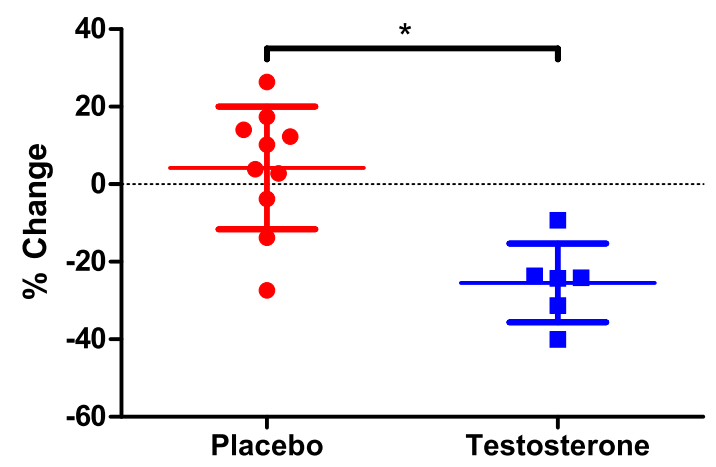

b Effective Arterial Elastance (Ea)

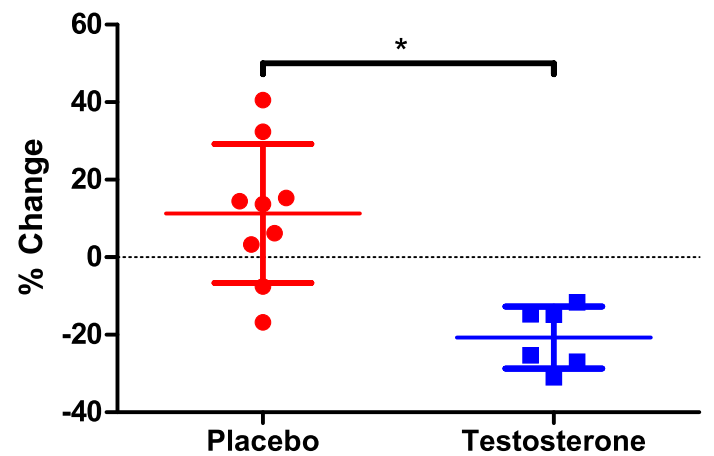

C Ventricular Vascular Coupling (Ea/Ees)

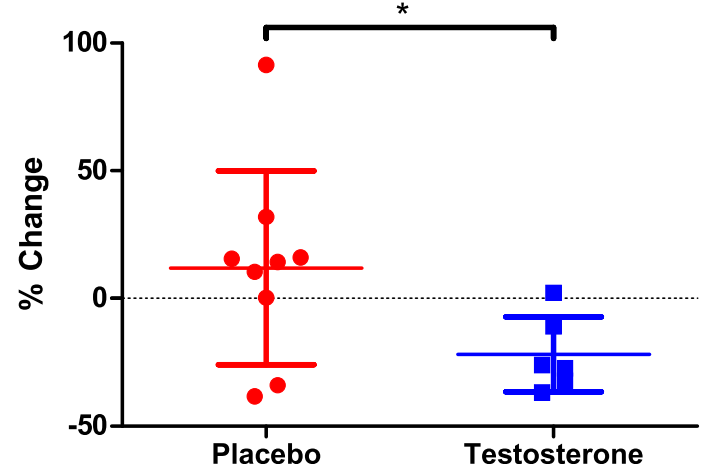

Fig. 3 Percent change in systemic vascular resistance (a), arterial elastance (b), and ventricular-vascular coupling (c) from pre to postintervention in placebo (red) and testosterone (blue)

testosterone, suggesting that testosterone may be an important intervention for patients with poor LV ejection fraction. Nevertheless, these findings should be interpreted with caution given the small sample size. Collectively, these findings indicate that testosterone supplementation may be an effective intervention to improve cardiac function; however, larger trials are needed 
to address whether testosterone is fully protective against cardiac atrophic remodeling in patients with advanced cancers.

The mechanisms underlying testosterone-induced cardioprotection are not fully known; however, may involve both cardiac and vascular systems. Cardiomyocytes contain receptors with a high affinity for testosterone [13] and in vitro studies of nonhuman cardiac myocytes found that testosterone can decrease action potential duration (thereby altering repolarization) and peak shortening times [27]. Testosterone is also an acute vasodilator [28] and lowers blood pressure [29]. Thus, understanding how the heart and systemic vasculature function independently as well as how they interact (termed ventricular-arterial coupling) is important when evaluating global cardiovascular function [17]. In the present study we found that testosterone had beneficial effects on vascular parameters (e.g., Ea, SVR), which in turn, improved ventricular-vascular coupling compared to placebo-treated patients. Future studies evaluating the mechanistic underpinnings of the effects of testosterone on cardiac and peripheral vasculature in the cachectic setting are needed.

In current clinical practice, the discipline of cardiooncology traditionally focuses on the detection and management of cancer treatment-induced reductions in cardiac function (i.e., LVEF), and/or development of overt heart failure [30-32] and coronary artery disease [33]. Intriguingly, based on conventional metrics, all patients in the current study have 'normal' cardiac function (e.g., LVEF > 55\%). Nevertheless, there is burgeoning interest in detection of early and subclinical therapyrelated cardiac consequences, including changes in cardiac size and ventricular-vascular coupling. Furthermore, techniques such as assessing the heart during exercise has provided novel prognostic information beyond traditional resting cardiac measures in patients with breast cancer [34]. Collectively, these findings indicate that evaluating cardiac morphology and function in the cachectic setting, as well as evaluating other metrics such as cardiorespiratory fitness and cardiac function during exercise will be important in the design of future intervention trials. Given the systemic effects of cachexia, evaluation of multimodal approaches including nutritional support, pharmacological intervention, and exercise training will be important for this high-risk population.

A number of study limitations should be considered. First, the trial was designed to assess the effect of testosterone treatment on lean body mass, and changes in cardiac parameters were not predefined outcome measures. Second, our sample size was small. Trials with larger samples sizes are needed to definitively assess the efficacy of testosterone on cardiac morphology and function in advanced cancers. Third, our subject population was predominantly female, and although androgens stimulate skeletal muscle protein synthesis similarly between men and women [35], potential sex differences in cardiac androgen receptor density [36] and the mechanisms of response to testosterone treatment may limit the generalizability of our findings. For instance, following exercise training the development of LV hypertrophy and increase in cardiorespiratory fitness in females was markedly blunted compared with males [37]; whether females have blunted response to testosterone compared to males should be addressed in future studies. Finally, to fully characterize the physiological importance of atrophic remodeling and potential efficacy of testosterone supplementation, there is a need to move beyond the study of global measures of LV function at rest. For example, reduced strain and strain rate revealed impaired myocardial function prior to LVEF decline [38] in cancer patients treated with anthracycline-containing therapy. Thus, evaluation of cardiac and vascular function with advanced imaging techniques at rest [39], as well as responses to a peak cardiopulmonary exercise test [40], may provide important insight into characterizing the 'cachectic heart'.

\section{Conclusions}

In patients with advanced cancers, testosterone was associated with favorable changes in left ventricular systolic function, arterial elastance, and ventricular-arterial coupling. There are promising multisystem benefits of testosterone; however, given the small sample size in the current study, further evaluation in a larger randomized trial is warranted.

\section{Additional file}

Additional file 1: Absolute change in cardiac outcomes. (PDF $42 \mathrm{~kb}$ )

\section{Author contributions}

Conceptualization, MSM; methodology, MSM, MK, RJU, WJD, TJW; formal analysis, JMS, ELD, AC, DJ; investigation, ELD, MK, CPD, KMR, MSM, WJD, TJW; resources, MK, SMC, MW, SH, GR, RJU, MSM; data curation, ELD, KMR;

writing-original draft preparation, JMS, ELD, AC, MSM; writing-review and editing, all authors; funding acquisition, MSM. All authors read and approved the manuscript.

\section{Availability of data and materials}

The datasets used and/or analysed during the current study are available from the corresponding author on reasonable request.

\section{Ethics approval and consent to participate}

This study was conducted in accordance with the principles of the Declaration of Helsinki and approved by the Institutional Review Board at the University of Texas Medical Branch. Written informed consent was obtained from all patients prior to participation.

Consent for publication

Not applicable. 


\section{Competing interests}

The authors declare that they have no competing interests.

\section{Author details}

'Department of Medicine, Memorial Sloan Kettering Cancer Center, New York, NY, USA. ${ }^{2}$ Department of Internal Medicine, The University of Texas Medical Branch, Galveston, TX, USA. ${ }^{3}$ Department of Anesthesiology, The University of Texas Medical Branch, Galveston, TX, USA. ${ }^{4}$ Department of Otolaryngology, The University of Texas Medical Branch, Galveston, TX, USA. ${ }^{5}$ Department of Preventive Medicine and Community Health, The University of Texas Medical Branch, Galveston, TX, USA. ${ }^{6}$ Department of Radiation Oncology, The University of Texas Medical Branch, Galveston, TX, USA. ${ }^{7}$ Department of Gynecologic Oncology, The University of Texas Medical Branch, Galveston, TX, USA. ${ }^{8}$ Department of Health and Kinesiology, Texas A\&M University, 155 Ireland St., College Station, TX TX 77845, USA.

\section{Received: 15 May 2019 Accepted: 31 July 2019}

Published online: 07 August 2019

\section{References}

1. Fearon K, Strasser F, Anker SD, Bosaeus I, Bruera E, Fainsinger RL, et al. Definition and classification of cancer cachexia: an international consensus. Lancet Oncol. 2011;12(5):489-95.

2. von Haehling S, Anker SD. Prevalence, incidence and clinical impact of cachexia: facts and numbers-update 2014. J Cachexia Sarcopenia Muscle. 2014;5(4):261-3.

3. Antoun S, Birdsell L, Sawyer MB, Venner P, Escudier B, Baracos VE. Association of skeletal muscle wasting with treatment with sorafenib in patients with advanced renal cell carcinoma: results from a placebocontrolled study. J Clin Oncol. 2010;28(6):1054-60.

4. Kazemi-Bajestani SM, Becher H, Fassbender K, Chu Q, Baracos VE. Concurrent evolution of cancer cachexia and heart failure: bilateral effects exist. J Cachexia Sarcopenia Muscle. 2014;5(2):95-104

5. Murphy KT. The pathogenesis and treatment of cardiac atrophy in cancer cachexia. Am J Physiol Heart Circ Physiol. 2016;310(4):H466-77.

6. Gordon W. The cardiac Dulness in cases of Cancer. Med Chir Trans. 1904;87: 327-37.

7. Hellerstein HK, Santiago-Stevenson D. Atrophy of the heart; a correlative study of 85 proved cases. Circulation. 1950;1(1):93-126, illust.

8. Springer J, Tschirner A, Haghikia A, von Haehling S, Lal H, Grzesiak A, et al. Prevention of liver cancer cachexia-induced cardiac wasting and heart failure. Eur Heart J. 2014;35(14):932-41.

9. Tian M, Asp ML, Nishijima Y, Belury MA. Evidence for cardiac atrophic remodeling in cancer-induced cachexia in mice. Int J Oncol. 2011;39(5): $1321-6$.

10. Emmelot-Vonk MH, Verhaar HJ, Nakhai Pour HR, Aleman A, Lock TM, Bosch $J \mathrm{~L}$, et al. Effect of testosterone supplementation on functional mobility, cognition, and other parameters in older men: a randomized controlled trial. JAMA. 2008;299(1):39-52.

11. Borst SE, Yarrow JF, Conover CF, Nseyo U, Meuleman JR, Lipinska JA, et al. Musculoskeletal and prostate effects of combined testosterone and finasteride administration in older hypogonadal men: a randomized controlled trial. Am J Physiol Endocrinol Metab. 2014;306(4):E433-42.

12. Sheffield-Moore M, Dillon EL, Casperson SL, Gilkison CR, Paddon-Jones D, Durham WJ, et al. A randomized pilot study of monthly cycled testosterone replacement or continuous testosterone replacement versus placebo in older men. J Clin Endocrinol Metab. 2011;96(11):E1831-7.

13. Kinson GA, Layberry RA, Hebert B. Influences of anabolic androgens on cardiac growth and metabolism in the rat. Can J Physiol Pharmacol. 1991; 69(11):1698-704

14. Toma M, McAlister FA, Coglianese EE, Vidi V, Vasaiwala S, Bakal JA, et al. Testosterone supplementation in heart failure: a meta-analysis. Circ Heart Fail. 2012;5(3):315-21.

15. Wright TJ, Dillon EL, Durham WJ, Chamberlain A, Randolph KM, Danesi C, et al. A randomized trial of adjunct testosterone for cancer-related muscle loss in men and women. J Cachexia Sarcopenia Muscle. 2018;9(3):482-96.

16. Lang RM, Bierig M, Devereux RB, Flachskampf FA, Foster E, Pellikka PA, et al. Recommendations for chamber quantification: a report from the American Society of Echocardiography's quidelines and standards committee and the chamber quantification writing group, developed in conjunction with the
European Association of Echocardiography, a branch of the European Society of Cardiology. J Am Soc Echocardiogr. 2005;18(12):1440-63.

17. Kelly RP, Ting CT, Yang TM, Liu CP, Maughan WL, Chang MS, et al. Effective arterial elastance as index of arterial vascular load in humans. Circulation. 1992;86(2):513-21.

18. Scott JM, Esch BT, Haykowsky MJ, Warburton DE, Toma M, Jelani A, et al. Cardiovascular responses to incremental and sustained submaximal exercise in heart transplant recipients. Am J Physiol Heart Circ Physiol. 2009;296(2):H350-8.

19. Ewer MS, Ewer SM. Cardiotoxicity of anticancer treatments: what the cardiologist needs to know. Nat Rev Cardiol. 2010;7(10):564-75.

20. Ferreira de Souza T, Quinaglia ACST, Osorio Costa F, Shah R, Neilan TG, Velloso L, et al. Anthracycline therapy is associated with cardiomyocyte atrophy and preclinical manifestations of heart disease. JACC CardiovasC Imaging. 2018;11(8):1045-55.

21. Neilan TG, Coelho-Filho OR, Pena-Herrera D, Shah RV, Jerosch-Herold M, Francis SA, et al. Left ventricular mass in patients with a cardiomyopathy after treatment with anthracyclines. Am J Cardiol. 2012:110(11):1679-86.

22. Advani SM, Advani PG, VonVille HM, Jafri SH. Pharmacological management of cachexia in adult cancer patients: a systematic review of clinical trials. BMC Cancer. 2018;18(1):1174.

23. Bell JR, Bernasochi GB, Varma U, Raaijmakers AJ, Delbridge LM. Sex and sex hormones in cardiac stress--mechanistic insights. J Steroid Biochem Mol Biol. 2013;137:124-35.

24. Kim C, Bebu I, Braffett B, Cleary PA, Arends V, Steffes M, et al. Testosterone and cardiac mass and function in men with type 1 diabetes in the epidemiology of diabetes interventions and complications study (EDIC). Clin Endocrinol. 2016;84(5):693-9.

25. Subramanya $V$, Zhao D, Ouyang $P$, Ying W, Vaidya D, Ndumele CE, et al. Association of endogenous sex hormone levels with coronary artery calcium progression among post-menopausal women in the multi-ethnic study of atherosclerosis (MESA). J Cardiovasc Comput Tomogr. 2018.

26. Gianatti EJ, Hoermann R, Lam Q, Dupuis P, Zajac JD, Grossmann M. Effect of testosterone treatment on cardiac biomarkers in a randomized controlled trial of men with type 2 diabetes. Clin Endocrinol. 2016;84(1):55-62.

27. Kimura N, Mizokami A, Oonuma T, Sasano H, Nagura H. Immunocytochemical localization of androgen receptor with polyclonal antibody in paraffin-embedded human tissues. J Histochem Cytochem. 1993:41(5):671-8.

28. Pugh PJ, Jones TH, Channer KS. Acute haemodynamic effects of testosterone in men with chronic heart failure. Eur Heart J. 2003:24(10):909-15.

29. Anderson FH, Francis RM, Faulkner K. Androgen supplementation in eugonadal men with osteoporosis-effects of 6 months of treatment on bone mineral density and cardiovascular risk factors. Bone. 1996;18(2):171-7.

30. Zamorano JL, Lancellotti P, Rodriguez Munoz D, Aboyans V, Asteggiano R, Galderisi M, et al. 2016 ESC position paper on cancer treatments and cardiovascular toxicity developed under the auspices of the ESC Committee for practice guidelines: the task force for cancer treatments and cardiovascular toxicity of the European Society of Cardiology (ESC). Eur Heart J. 2016;37(36):2768-801.

31. Hamo CE, Bloom MW, Cardinale D, Ky B, Nohria A, Baer L, et al. Cancer therapy-related cardiac dysfunction and heart failure: part 2: prevention treatment, guidelines, and future directions. Circ Heart Fail. 2016;9(2):e002843.

32. Saiki H, Petersen IA, Scott CG, Bailey KR, Dunlay SM, Finley RR, et al. Risk of heart failure with preserved ejection fraction in older women after contemporary radiotherapy for breast Cancer. Circulation. 2017;135(15):1388-96.

33. Darby SC, Ewertz M, McGale P, Bennet AM, Blom-Goldman U, Bronnum D, et al. Risk of ischemic heart disease in women after radiotherapy for breast cancer. N Engl J Med. 2013;368(11):987-98.

34. Howden EJ, Bigaran A, Beaudry R, Fraser S, Selig S, Foulkes S, et al. Exercise as a diagnostic and therapeutic tool for the prevention of cardiovascular dysfunction in breast cancer patients. Eur J Prev Cardiol. 2019;26(3):305-15.

35. Sheffield-Moore M, Paddon-Jones D, Casperson SL, Gilkison C, Volpi E, Wolf $\mathrm{SE}$, et al. Androgen therapy induces muscle protein anabolism in older women. J Clin Endocrinol Metab. 2006;91(10):3844-9.

36. McCrohon JA, Death AK, Nakhla S, Jessup W, Handelsman DJ, Stanley KK, et al. Androgen receptor expression is greater in macrophages from male than from female donors. A sex difference with implications for atherogenesis. Circulation. 2000;101(3):224-6.

37. Howden EJ, Perhonen M, Peshock RM, et al. Females have a blunted cardiovascular response to one year of intensive supervised endurance training. J Appl Physiol (1985). 2015;119:37-46. 
38. Hare JL, Brown JK, Leano R, Jenkins C, Woodward N, Marwick TH. Use of myocardial deformation imaging to detect preclinical myocardial dysfunction before conventional measures in patients undergoing breast cancer treatment with trastuzumab. Am Heart J. 2009;158(2):294-301.

39. Scott JM, Martin D, Ploutz-Snyder R, et al. Efficacy of Exercise and Testosterone to Mitigate Atrophic Cardiovascular Remodeling. Med Sci Sports Exerc. 2018;50:1940-49.

40. Scott JM, Zabor EC, Schwitzer E, Koelwyn GJ, Adams SC, Nilsen TS, et al. Efficacy of Exercise Therapy on Cardiorespiratory Fitness in Patients With Cancer: A Systematic Review and Meta-Analysis. J Clin Oncol. 2018: JCO2017775809.

\section{Publisher's Note}

Springer Nature remains neutral with regard to jurisdictional claims in published maps and institutional affiliations.

Ready to submit your research? Choose BMC and benefit from:

- fast, convenient online submission

- thorough peer review by experienced researchers in your field

- rapid publication on acceptance

- support for research data, including large and complex data types

- gold Open Access which fosters wider collaboration and increased citations

- maximum visibility for your research: over $100 \mathrm{M}$ website views per year

At BMC, research is always in progress.

Learn more biomedcentral.com/submissions 